\title{
Important Dimensions of Digital Divide: A case study of NADRA Portal Pakistan
}

\author{
Shah Hassan (Corresponding author) \\ School of Public Affairs, University of Science and Technology of China, China \\ E-mail: shahhassan@mail.ustc.edu.cn
}

\begin{abstract}
Ali Madad
School of Public Affairs, University of Science and Technology of China, China E-mail: ali@mail.ustc.edu.cn
\end{abstract}

\section{Asma}

School of Public Affairs, University of Science and Technology of China, China E-mail: asma@mail.ustc.edu.cn

\section{Narain Das}

School of Public Affairs, University of Science and Technology of China, China E-mail: narain_das1990@ hotmail.com

\section{Sadia Akhtar}

School of Public Affairs, University of Science and Technology of China, China E-mail: sadia@mail.ustc.edu.cn

\section{Noor Jehan}

School of Public Affairs, University of Science and Technology of China, China E-mail: world.economics14@gmail.com

Received: October 9, 2018 Accepted: October 25, 2018 Accepted: January 29, 2019 doi:10.5296/ber.v9i1.14290 URL: https://doi.org/10.5296/ber.v9i1.14290 


\section{Abstract}

The aim and purpose of this paper is to contribute and understand the nature of the digital divide as it affects the Pakistani citizens, who are users of NADRA online portal. To study the digital divide; NADRA is the best case because this institute is rich in this context; it is the most developed e-services provider of the government of Pakistan. It is compulsory for every citizen of Pakistan to get register with NADRA to avail facilities of Travelling within and outside the country, to have a bank account, apply for jobs, having a house, driving license and many more. To conduct the survey data was collected from the citizen of Pakistan living in Turkey, China, and Pakistan. 355 responses were collected, and ANOVA and t-test were perform using SPSS-16. Technology Acceptance Model (TAM) was used to measure the attitude and intention of individuals towards e-services provided by government whereas, demographic, geographic, education and computer and internet experiences are the digital divide dimensions. Results reveal that location, education, and computer and internet significantly affect the user attitude and intention whereas gender and age are not significant. Overall, this study offers an understanding of complex of digital divide concepts.

Keywords: E-governance, E-Services, ICT, Digital Divide, Adoption, TAM

\section{Introduction}

E-government plays an important role and emphasizes on enhancing the relationship between citizens and government using information and communication technologies (ICT) (Sipior, Ward, \& Connolly, 2011; Asgarkhani, 2005). E-services strive to change the way government works by bringing service revolution through ICT; through the evolution of e-services by governments, technologies enable citizens to interact and communicate with the government in a better and accessible manner (Tayo, Thompson, \& Thompson, 2015). It can predict that governments would take advantage of modern technology to communicate with its citizen. However, a citizen who is the primary user of e-services has less or minimum access to those services (Pilling \& Boeltzig, 2007). With the evolution of e-services, the most challenging is that the digital divide must be addressed (Pilling \& Boeltzig, 2007; Rossel \& finger, 2007). Digital divide refers to economic and social inequality that exists between individuals belong from different geographical, demographical and educational background with regards to access to information and communication tools which includes television, internet, computer and mobile phones (Loges \& Jung, 2001). The digital divide also referred as the difference between an individual's skills and abilities to utilize and get benefited from technology. The digital divide is affected by demographics, geographic and socio-economic variables that are age, gender, location, and education (Norris, 2000). According to Norris (2006) and Dijk \& K (2003) digital divide exists in developing as well as developed nations. In developed countries, the digital divide is present because of low literacy and old age user because they are lack of skills and ability to access information using technology. In developing countries like Pakistan, India, China, and Russia, they are lagging because less effort is being put to reduce the digital divide, in these countries, ICT infrastructure is less developed and government put a restriction on e-commerce development. Developing countries are facing financial and resources challenges in developing ICT infrastructure (Imhonopi \& Urim, 2015). 
However, with the development of infrastructure government has the opportunity to work efficiently and effectively and support economic development.

Apart from challenges and opportunities, there are benefits associated with the advancement of information, technology, and communication structure. Knowing the opportunities, developing countries are investing in mounting and cultivating e-services, to update and improve access to information regarding government services, policies making processes. By investing resources and money on developing ICT infrastructure government can achieve two-mile stones these are efficiency and second is a population of the country is motivated and encouraged to learn computer and internet skills.

Researchers focus on the importance and growth of e-services provided by the government in developing nations. Research scientist claims that there is a requirement to analyse digital divide in the context of e-government services especially in developing nations like Pakistan. Partial studies on the topic digital divide and e-government services in Pakistan demonstrate Pakistan is facing weak ICT infrastructure, especially in rural areas, due to lack of government interest and willingness to invest on ICT related issues. In context of E-government adoption, digital divide occurs among population due to low and very slow internet usage penetration and poor ICT infrastructure. It is essential to address Digital divide because it is interrelated to political, socio-economic and educational issues, reduction in the digital divide has the potential to reduce social inequalities.

Pakistan is a developing country, and due to CPEC country is progressing and many economies are investing in the country and help Pakistan in developing its infrastructure, at the same time country is facing challenges in developing ICT infrastructure and built a system through which it can educate its large population. This research paper focuses on e-government services, and the basis of the study is NADRA (National Database and Registration Authority) (Haide \& Shuwen, 2015). It is a well-developed institute of government, and it is compulsory for every citizen of Pakistan to get register with NADRA to have an identity that individual belongs to Pakistan. Also, it is mandatory for every citizen if he/she wants to have a passport, bank account or to work with any organization within the country. The study aims to explore the influence of geographical location, demographics (age, gender) and education on digital divide dimensions these are computer facilities and internet experience, e-government services experience and trustworthiness. By that model is proposed for further analysis.

The flow and structure of this paper are as follow; first theoretical background is presented, then literature review, and hypothesis building, which is followed by research methodology and empirical results, discussion, and implications.

\section{Theoretical Background}

Davis (1989) proposed Technology Acceptance Model (TAM), to foresee the technology acceptance among the users. Research scientists used (TAM) to forecast the intention of the user to accept technology. Therefore, it can be interpreted that TAM has considerably influenced the technology adoption and its usage (Wang, Rau, \& Salvendy, 2011). Benbasat 


\section{Macrothink Institute ${ }^{\mathrm{TM}}$}

\& Barki (2007) and Chen (2016) investigated individual intention to embrace new technology in developing countries and proposed TAM model to make it appropriate and according to situation perspective. TAM is derived from Theory of Reasoned Action (TRA) and establishes that individual transform their behaviour according to accepted technology (Ajzen \& Fishbein, 1980). Two primary constructs that measures individual behaviour towards technology. These are ease of use and usefulness. This research study focuses on the impact of the digital divide and e-services usage provided by governments. According to Bélanger \& Lemuria (2009) and Ebbers, Jansen, \& Deursen (2016) the digital divide is defined as the gap between the population with access to IC technology and those who have no access to it. Helbig, il-Garcia, \& Ferro (2009) characterized digital divide as the unequal distribution or access to ICT. Min (2010) and Deursen \& Dijk (2010) refer digital divide is the ability and skills of individuals to utilize and be benefited from ICT. (Antonio \& Tuffley (2014) explains digital divide regarding demographics, according to him, access to computer facilities and information technology skills depends and affected when focusing on gender (male and female) whereas Servon \& Nelson (2001) explains digital divide more broadly that it is caused or occurred due to socio-economic and educational inequalities. Based on the discussion, the researcher suggested multi-dimensional digital divide model, which assist in understanding and exploring the relationship between variables.

The study aims to explore the effect of geographical location, demographics, geographical and education, computer and internet experience of the user on ease of use and effectiveness of e-government services and their intention to use it. After examining the literature model is proposed for further analysis.

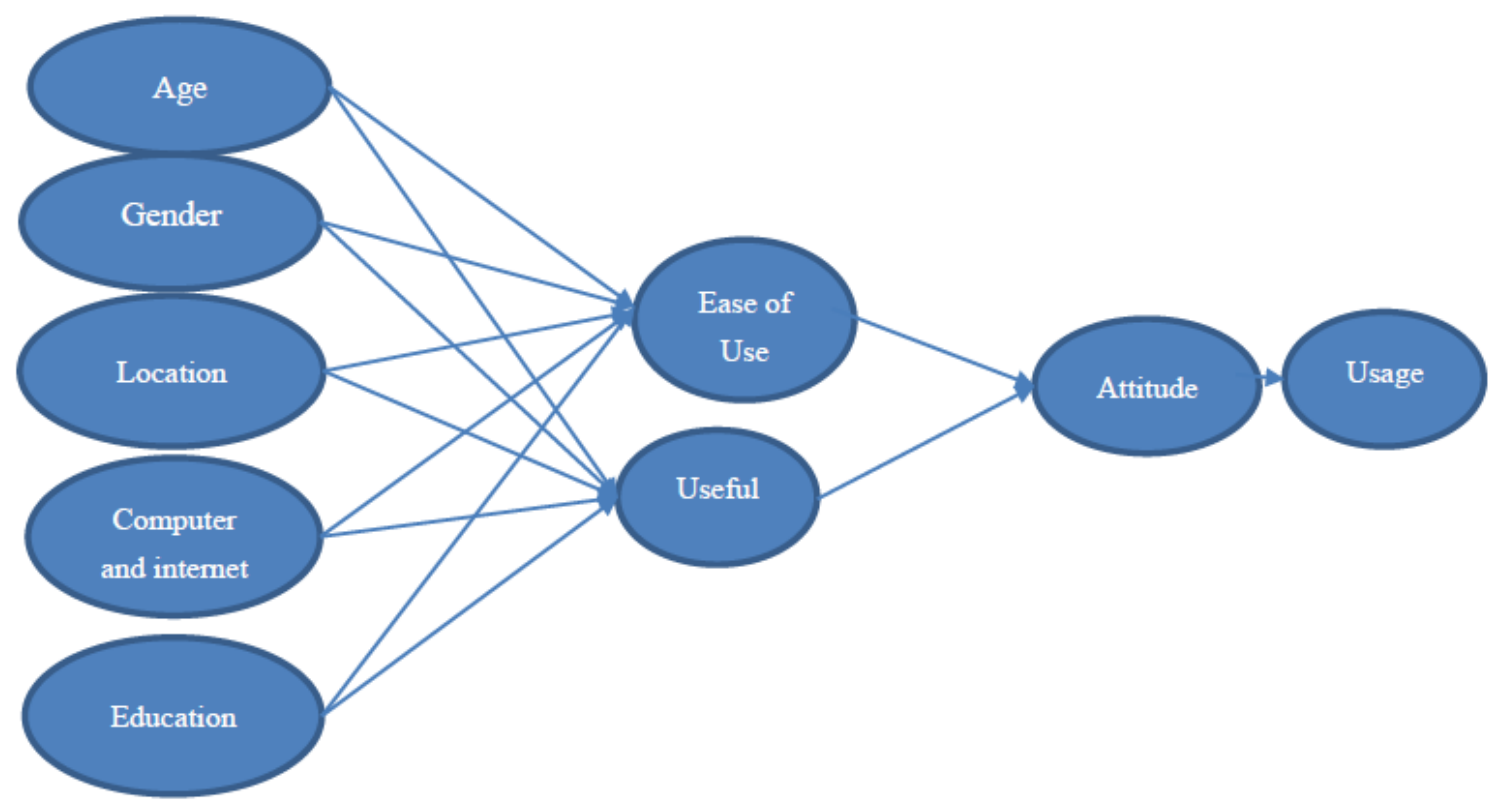

Figure 1. Propose Model

Literature Review and Hypothesis building 


\subsection{Demographic, Geographical, Education and Computer and Internet Experience}

The previous research indicates that contributors in digital divide are demographics and socio-economic and educational factors. (Antonio \& Tuffley (2014) and (Wasserman \& Richmond-Abbott (2005) revealed that demographics (age and gender) affects the digital divide, where male are in larger percentage than women are in using internet and computer facilities. Where Hilbert (2011) analysed that there is a relationship between age and gender, young blooded women are challenging their counterpart males in the context of internet and computer usage. In developed and developing economies, age significantly affects internet and computer usage. As it is evident from the research, that older people are less interested and enthusiast in using computer and internet as compared to young individuals. According to Norris (2006-2000) people living in urban and rural areas are a contributor to study digital divide. Researchers examine that persistence of digital divide depends upon the individuals living in urban and rural areas. In urban areas, internet usage is higher because people living in urban areas have access to the public internet as compared to rural areas. In the same context, researchers compares developed and developing countries in terms of ICT infrastructure, computer skills, wide range, and affordable internet connections. Because of the low living standards, poor infrastructure developing countries are lagging in e-government services. White (2012) urges that not every individual in the society have access to the internet because of the wide gap between rich, poor, urban and rural areas facilities and infrastructure. Third world countries are significantly affected by digital divide because of poor governance and infrastructure. Improvement in these issues may solve digital divide problems.

The next variable is education and computer skills that up to what extent educational background of the respondents may affect the digital divide among individuals. According to Vicente and Lopez (2011), education is one of the most potent and significant components which measures the ability and capability of individual to experience technology and access technology. Zhong (2011) urges that development of ICT infrastructure encourage individuals to learn and promote education at school, college, and university level to be benefited from the facilities available. Literate and educate individuals to keep themselves up to date with information and knowledge through internet and computer usage as compared to people who are less educated (Anderson K. , 2001). Belanger \& Carter (2009) explain the internet and computer experience as the skills and ability of the individuals to utilize and experience different activities using computer and internet. Zinyama \& Nhema (2016) refer internet and computer experience as the operational and technical skills to use internet and computer to evaluate, explore and exploit information to get essential knowledge that benefits them in achieving goals.

\subsection{Perceived Ease of Use and Usefulness}

The primary constructs of TAM are "perceived usefulness" and "perceived ease of use" which are considered as the motivational factors which encourage individual to accept and practice new techniques. Perceived Usefulness is the degree to which individual performance enhances by using a particular technology (Davis, 1989). By using that particular technology 
user get valuable results and are appreciated by people who think that the technology is the wastage of time (Rauniar, Rawski, Yang, \& Johnson, 2014; Zulfiqar, Sarwar, Aziz, Chandia, $\&$ Khan, 2018). Whereas; ease of use is the degree to which individual feel relax and free from physical and mental effort while using specific technology (Davis, 1989). Researcher states that individual adopt technology because of functionalities and benefits associated with them rather than its ease of use. With the age, individuals believe that their cognitive ability to learn a new technology is reduced (Hoofnagle, King, Li, \& Turow, 2010) hence; older people with a limited computer and internet usage experiences perceive that the latest technology can not benefit them. Moreover, older people indulge themselves in activities that satisfied their emotional needs, so older people are less likely to use computer and internet technology because these technologies are information based rather than emotional. Adopting a new technology required advanced knowledge about complex and modern technologies such as computer and internet knowledge (Lenhart, Purcell, Smith, \& Zickuhr, 2010) highly educated individuals have an advantage, and they adopt new technologies readily because they know to understand it as compared to people who are less educated.

Based on the above literature following

H1 (a): Age has a significant impact on ease of perceived usefulness of e-services by government

H1 (b): Gender has a significant impact on ease of perceived usefulness of e-services by government

H1(c): Location has a significant impact on ease of perceived usefulness of e-services by government

H1 (d): Education has a significant impact on ease of perceived usefulness of e-services by government

H1 (e): Computer and internet experience has a significant impact on the perceived usefulness of e-services by government

H2 (a): Age has a significant impact on ease of perceived ease of use of e-services by government

H2 (b): Gender has a significant impact on ease of perceived ease of use of e-services by government

H2(c): Location has a significant impact on ease of perceived ease of use of e-services by government

H2 (d): Education has a significant impact on ease of perceived ease of use of e e-services by government

H2 (e): Computer and internet experience has significant impact perceived ease of use of e-services by government

H3 (a): Perceived ease of use has a significant effect on usage of e-services by government 
H3 (b): Perceived usefulness has a significant effect on usage of e-services by government

H4: Attitude of using e-government services has a significant impact on the usage of these e-services

\section{Research Context}

Pakistan has been working for the development of e-services by the government since 2002 . The government aims to enhance the efficiency of the public administrative and legislative institutes. Government is releasing funds to extend e-government services at national as well as at provincial level. However, due to poor ICT infrastructure, electricity shortage and low access to internet and computer facilities, Pakistan is facing challenges and problems in this sector. Due to a weak educational system and interconnectivity between government institutes, people are reluctant to use e-government services. However, interestingly smartphone users in Pakistan are increasing day by day; there is a potential that the government removes the digital divide by providing internet facility at mobile phones that are useful and easy to use.

The context of this study is e-government services provided by NADRA. NADRA developed e-services to support and distribute information among citizens of Pakistan which help them is many processes like new passport, visa application, online payment for renewal of passport. NADRA e-service portal provides equal opportunity to a citizen living in Pakistan as well as abroad to take advantage of this portal. NADRA considered and acknowledged as the successful e-services implementer, but still, it is facing a significant number of challenges.

\section{Research Methodology}

This research paper uses a quantitative method to collect data from respondents; self-administrated and online survey techniques were used to measure the digital divide and adoption of e-government services. The closed-ended questionnaire was used to support the ease of completion and ease of analysis. This questionnaire includes demographical, geographical and educational and computer and internet experience questions. The current study is apprehensive, and it examines the digital divide and intention of operators to use e-government services.

Due to a shortage of resources and time, the convenience sampling method was employed to collect data from respondents who are living in Pakistan and abroad (China and Turkey). Easy and cost-efficient techniques were adopted to collect data from the target population. Techniques include a direct method and using online survey software like survey monkey. Moreover, questionnaires were distributed using mobile messengers like WHATSAPP and WECHAT. As well opportunity sample technique was used in which the researcher chose respondent from his/her social network, the researcher took advantage of the personal network and invite them to fill online survey form. In total 478 questionnaires were circulated among respondents out of which 355 responses where consider fit for further analysis. 


\section{Measures}

All the constructs were measured using multiple scales; questionnaires were adapted from different research articles with revisions of words and sentences to meet research objective and to ensure the validity of constructs. Questionnaire of the construct are adopted from Ease of use and perceived usefulness (Miloševic, Zivkovic, Manasijevic, \& Nikolic, 2015); usage behavior (Ma, Chan, \& Chen, 2016). Questionnaire to measure attitude towards e-government services were adopted from a porter and don't 2006. To measure items 7-point Likert scale is used to quantify the answers of the respondent, where 1-strongly disagree, 4neutral, and 7-strongly agree. Whereas for age, gender, was measured through a single item on the other hand location, education and computer and internet experience were open-ended questions asking for education level and some year experience of using computer and internet.

For this data was collected from both males and females that are citizens of Pakistan and are living in Pakistan and abroad. Data is collected from a respondent who is educated and has the experience to use NADRA e-services at least once in their life. Pilot test study was conducted before the collection of data from respondents to confirm the validity of the questionnaire. At the first stage, five respondents were requested to fill and evaluate the questionnaire design. In the second phase, 15 respondents were requested to fill questionnaires, through this process researcher was able to diagnose the concerns regarding words and concept of the questionnaire and with little modification, and it was circulated among the respondents. According to Bell and Fink (2005) pilot testing benefits academic scientists to ensure the content validity of the questionnaire.

Demographic information of the respondents includes age, gender, education, and computer and internet experience are shown in table 1.

Table 1. Demographics Information

\begin{tabular}{|l|l|l|}
\hline Demographic information & Frequency & Percentage \\
\hline Age & & \\
\hline $18-22$ & 91 & 36.4 \\
\hline $23-26$ & 98 & 39.2 \\
\hline $27-32$ & 54 & 21.6 \\
\hline $33-$ to 40 & 7 & 2.8 \\
\hline Gender & & \\
\hline Male & 135 & 54 \\
\hline Female & 115 & 46 \\
\hline Education & & \\
\hline High School & 39 & 15.7 \\
\hline Graduate & 19 & 7.80 \\
\hline Post-graduate & 119 & 47.50 \\
\hline Ph.D. & 73 & 29 \\
\hline Uneducated & & \\
\hline
\end{tabular}




\begin{tabular}{|l|l|l|}
\hline Location & & \\
\hline Pakistan (Rural and Urban) & 172 & 47.77 \\
\hline China & 93 & 25.83 \\
\hline Turkey & 95 & 26.38 \\
\hline Computer and internet experience & & \\
\hline More than 5 years & 15 & 5.76 \\
\hline More than 8 years & 50 & 20.15 \\
\hline More than 10 years & 89 & 35.5 \\
\hline More than 15 years & 96 & 38.59 \\
\hline
\end{tabular}

\section{Data Analysis}

To understand the fundamental relationship between the variables quantitative analysis used. All the items used to test hypotheses were first to validate by using factor loading and Cronbach alpha tests. Then to test hypotheses multiple regression analysis was employed. Multiple regression analysis permits researchers to control variables and then classify incremental variables that explain observed variable to test hypotheses. To perform multiple regression analysis, two-step tests were conducted to check validity and reliability of the data. The first step is to perform exploratory factor analysis (EFA) and the second step is principal components analysis (CFA) (Hair, Anderson, Tatham, \& Black, 1998). To do analysis SPSS-21 was used. EFA was executed to measure the convergent validity of the constructs which can be examined by performing benchmark values of factor loadings are 0.5 , Cronbach Alpha is 0.6 where The Cronbach Alpha value for perceived ease of use is ".974"; perceived usefulness".951"; Attitude is ".978," and usage towards e-government services is ".892", AVE is 0.5, where AVE for Perceived usefulness"0.892", perceived ease of use "0.903", Attitude "0.937" and usage of e-government services " 0.738 " and CR are 0.7 and CR values for Perceived usefulness" 0.961 ", perceived ease of use "0.974", Attitude "0.978" and usage of e-government services "0.894”. (Hair, Anderson, Tatham, \& Black, 1998). Cronbach Alpha, $\mathrm{CR}$, and AVE values for all measurement scales show that data is fit for further analysis. Hence, results showed the excellent convergent validity and valid measure.

Table 2. Factor and Cross-loadings

\begin{tabular}{|l|l|l|l|l|l|}
\hline Constructs & Items & $\begin{array}{l}\text { Perceived } \\
\text { Ease of Use }\end{array}$ & $\begin{array}{l}\text { Perceived } \\
\text { Usefulness }\end{array}$ & Attitude & $\begin{array}{l}\text { Usage of } \\
\text { e-government }\end{array}$ \\
\hline \multirow{2}{*}{$\begin{array}{l}\text { Perceived } \\
\text { Ease of Use }\end{array}$} & EOU1 & .934 & .207 & .126 & .117 \\
\cline { 2 - 6 } & EOU2 & .928 & .185 & .137 & .119 \\
\cline { 2 - 6 } & EOU3 & .923 & .172 & .071 & .107 \\
\hline \multirow{3}{*}{$\begin{array}{l}\text { Perceived } \\
\text { Usefulness }\end{array}$} & PU1 & .163 & .946 & .092 & .143 \\
\cline { 2 - 6 } & PU2 & .196 & .914 & .115 & .137 \\
\cline { 2 - 6 } & PU3 & .215 & .898 & .092 & .175 \\
\hline \multirow{3}{*}{ Attitude } & AT1 & .129 & .128 & .936 & .221 \\
\cline { 2 - 6 } & AT2 & .129 & .095 & .931 & .262 \\
\cline { 2 - 6 } & AT3 & .133 & .134 & .923 & .259 \\
\hline Usage of & UEG1 & .176 & .199 & .191 & .856 \\
\hline
\end{tabular}




\begin{tabular}{|l|l|l|l|l|l|}
\hline \multirow{2}{*}{ e-government } & UEG2 & .183 & .205 & .295 & .835 \\
\cline { 2 - 6 } & UEG3 & .128 & .117 & .276 & .822 \\
\hline
\end{tabular}

Discriminate validity can be measured by comparing two tests. These are a correlation between the variables and AVE square root values of all variables. If AVE square root that is in diagonal and in bold have higher values than the correlation between variables studied, this point towards good discriminate validity (Fornell \& Larcker, 1981). Upright discriminate validity is shown in table 3 .

Table 3. Correlation, Mean, standardization and AVE Square root

\begin{tabular}{|l|l|l|l|l|l|l|}
\hline Sr. & Constructs & $\mathrm{M}(\mathrm{SD})$ & 1 & 2 & 3 & 4 \\
\hline 1 & Perceived Usefulness & $4.63(1.42)$ & 0.945 & & & \\
\hline 2 & Perceived Ease of Use & $4.39(1.48)$ & 0.400 & 0.950 & & \\
\hline 3 & Attitude & $5.26(1.38)$ & 0.278 & 0.305 & 0.968 & \\
\hline 4 & Usage of e-government services & $5.15(1.46)$ & 0.416 & 0.386 & 0.581 & 0.859 \\
\hline
\end{tabular}

\section{Research Hypotheses}

Validity and reliability test allow the researcher to perform further and test the proposed model. As all test performed shows excellent reliability and validity, research proceeds to path coefficient analysis using multiple regression analysis. The results indicate that H1 (a-e) depicts that age, location, education and computer and internet experience impact on perceived usefulness (PU) $(\mathrm{F}=31.091, \mathrm{p} \leq .001) \mathrm{H} 1(\mathrm{a}-\mathrm{b})$ are not significantly affect perceived usefulness whereas H1(c-e) shows that they significantly affect PU. H2 (a-e) depicts that age, location, education and computer and internet experience impact on perceived ease of use (EOU) ( $\mathrm{F}=$ $51.422, \mathrm{p} \leq .001) \mathrm{H} 1$ (a-b-d) are not significantly affected EOU whereas H1(c-e) shows that they significantly affect EOU. H3(a-b) depicts that perceived usefulness, perceived ease of use impact on attitude to use e-services by government $(\mathrm{F}=33.483, \mathrm{p} \leq .001)$; H3(a-b) are significantly affected attitude to individual towards use e-government services.H4 depicts that attitude leads the user to have an intention to use e-government services $(\mathrm{F}=33.483, \mathrm{p} \leq .001)$. H4 holds that attitude significantly impacts individual user behaviour.

Table 4. Results of Multiple Regression Analysis

\begin{tabular}{|l|l|l|l|l|l|l|}
\hline Dependent variable & Independent & $\begin{array}{l}\text { Adjusted } \\
R^{2}\end{array}$ & $\mathrm{~F}$ & $\beta$ & T-values & $\mathrm{p}$-values \\
\hline \multirow{4}{*}{$\begin{array}{l}\text { Perceived Usefulness } \\
\text { H1(a-e) }\end{array}$} & Gender & .230 & 31.091 & -.031 & -.799 & .425 \\
\cline { 2 - 7 } & Age & & & -.163 & -1.668 & .096 \\
\cline { 2 - 7 } & Location & & & .236 & 2.020 & .044 \\
\cline { 2 - 7 } & Education & & & .262 & 2.988 & .003 \\
\cline { 2 - 7 } & $\begin{array}{l}\text { Computer and } \\
\text { Internet Experience }\end{array}$ & & & & & \\
& Gender & .245 & 51.422 & -.024 & -.619 & .000 \\
\cline { 2 - 7 } $\begin{array}{l}\text { Perceived Ease of } \\
\text { Use H2(a-e) }\end{array}$ & Age & & & .025 & .255 & .799 \\
\cline { 2 - 7 } & Location & & & .284 & 2.448 & .015 \\
\hline
\end{tabular}




\begin{tabular}{|c|c|c|c|c|c|c|}
\hline & Education & & & .157 & 1.747 & .081 \\
\hline & $\begin{array}{l}\text { Computer and Internet } \\
\text { Experience }\end{array}$ & & & .133 & 3.341 & .001 \\
\hline \multirow{2}{*}{$\begin{array}{l}\text { Attitude } \\
\text { H3(a-b) }\end{array}$} & Perceived usefulness & .114 & 33.483 & .206 & 4.432 & .000 \\
\hline & Perceived ease of use & & & .200 & 4.299 & .000 \\
\hline $\begin{array}{l}\text { Usage } \\
\text { e-government } \\
\text { services } \mathrm{H} 4\end{array}$ & Attitude & .296 & 213.171 & .546 & 14.600 & .000 \\
\hline
\end{tabular}

***significant at the 0.001 level; **significant at the 0.01 level; *significant at the 0.05 level;

\section{Discussion}

E-government service implementation is the key and the most effective way to boost up the productivity of the government agencies and empower its citizen by providing them access to information. This research study recommends the Digital Divide and TAM Model depicts the relationship between the digital divide dimension and intention of the user to adopt e-services by the government. Results show the relationships between the dimensions of the digital divide regarding e-government services that are ease of use and usefulness of e-government services and how it makes the attitude of people and their behavioral intention towards it. The digital divide depicted by demographics, geographical and through educational, computer, and internet usage experience. Results show that age and gender are the variables that do not significantly affect their usage towards e-services. Whereas location, education and internet and computer experiences are the key factors that not only consider e-government services useful but also consider it easy to use. Results also depicts that people living in urban, in foreign countries, educated, and have internet and computer experiences have more attitude to use e-services and their behavioural intention also increasing with time. This study focuses on the choice of NADRA e-services that allow the researcher to do a comparison between the users of e-services of people living in Pakistan and Pakistani citizen living abroad. Study depicts that there is a substantial digital divide between the population living in Pakistan and living abroad and the people living in Urban and rural areas of the country. This study validates that in Pakistan small population has access to technology and internet services as compared to many developed and developing countries and that results in lack of e-services that are online banking, shopping, and other e-government services.

As the results depict that age and gender are not significant with ease of use and perceived usefulness this means that people are not aware of the benefits and usefulness of e-services provided the government. According to Pilling \& Boeltzig (2007) it is the responsibility of government organizations to aware its citizen about the benefits of e-services and how these e-services can transform their lives while engaging with technology. These innovative and awareness programs have the potential that encourages citizen to adopt e-services provided by the government. On the other, Pilling \& Boeltzig (2007) states that mostly government website is complex and less user-friendly. The government should focus not only on designing the layout user-friendly but also provide manual and educational material that let the readers train themselves to use the system. In this research paper we depict that location 
can be designated as the digital divide based on the hypothesis presented that location significantly affect the user attitude and intention towards using e-services provided by the government, (Park \& Kim, 2015) states that location is the place where people live in developing or developed countries, urban or rural areas. As Pakistan is a developing the country and has poor ICT infrastructure, has a low level of internet excess as compared to developed countries. Also, our research concludes that user living abroad has more attitude and intention to use NADRA e-services. Finally, education, computer, and internet experience are the more significant predictors of individual attitude and intention to use e-technology to perform their work (Puspitasari \& Ishii, 2016).

This study proposes practical implication; it is evident from the study that ICT infrastructure is very important for the successful implementation of e-government services. E-government services have the potential to track the inequalities and disparities of the society. The government should invest in e-government services, device policies, and structural reforms, as the number of mobile phone use is increasing day by day, the government should also focus on m-services. E-government services aim to improve the living standard of the people living in the region as through the e-services people can indulge in the political process and the proposed strategies and a mechanism to discourse the essential needs and wants that may benefit society as a whole. NADRA is the government institute if it is connected with other departments like property exchange, online tax payment, apply for employment and renewal of passport, driving license and many more, a citizen can be benefited, and the cause of economic destruction that is corruption and fraud can be minimized. In Pakistan, e-government services are at the beginning stage and every year government introduces new services, but the adoption among the citizen of Pakistan living to suburban and rural is very low because of lack of education and computer and internet experiences. There is a need to enforce these services so that people are encouraged to learn computer and internet skills to attain e-government services. This not increases literacy rate but also increase the employment rate.

\section{References}

Ajzen, I., \& Fishbein, M. (1980). Understanding Attitudes and Predicting Social Behaviour. NJ: Prentice-Hall, Englewood Cliffs.

Anderson, J. C., \& Gerbing, D. W. (1988). Structural Equation Modeling in Practice: A Review and Recommended Two-Step Approach. Psychological Bulletin, 103(3), 411-423. https://doi.org/10.1037/0033-2909.103.3.411

Anderson, K. (2001). Internet use among college students: An exploratory study. Journal of American College Health, 50(1), 21-26. https://doi.org/10.1080/07448480109595707

Antonio, A., \& Tuffley, D. (2014). The gender digital divide in developing countries. Future internet. https://doi.org/10.3390/fi6040673

Arbuckle, J. (2003). Amos 5.0 Update to the AMOS User's Guide. Chicago: Small Waters Corp. 
Asgarkhani, M. (2005). Digital government and its effectiveness in public management reform: A local government perspective. Public Management Review, 7(3), 465-487.

Bélanger, F., \& Lemuria, C. (2009). The impact of the digital divide on e-government use. . Communications of the ACM, 132-135.

Bell. (2005). Doing Your Research Project. Buckingham: Open University Press.

Benbasat, I., \& Barki, H. (2007). Quo vadis TAM? J. Assoc. Inform. Syst. https://doi.org/10.17705/1jais.00126

Chen, S.-Y. (2016). Green helpfulness or fun? Influences of green perceived value on the green loyalty of users and non-users of public bikes. Transport Policy.

ttps://doi.org/10.1016/j.tranpol.2016.01.014

Davis. (1989). Perceived usefulness, perceived ease of use, and user acceptance of information technology. MIS Quarterly, 13(3), 319-340. https://doi.org/10.2307/249008

Deursen, A. v., \& Dijk, J. v. (2010). Internet skills and the digital divide. New Media \& Society.

Dijk, J. v., \& K, H. (2003). The digital divide as a complex and dynamic phenomenon. The Information Society, 19(4), 315-326. https://doi.org/10.1080/01972240309487

Ebbers, W. E., Jansen, M. G., \& Deursen, A. J. (2016). Impact of digital divide on e-government: expending from channel choice to channel usage. Government Information Quarterly. https://doi.org/10.1016/j.giq.2016.08.007

Fink, A. (2003). The Survey Handbook. Thousand Oaks, CA: Sage. https://doi.org/10.4135/9781412986328

Fornell, C., \& Larcker, D. (1981). Evaluating structural equation models with unobservable variables and measurement error. Journal of Marketing Research, 18(1), 39-50.

https://doi.org/10.1177/002224378101800104

Haide, Z., \& Shuwen, C. (2015). Adoption of e-Government in Pakistan: Supply Perspective. International Journal of Advanced Computer Science and Applications.

Hair, J., Anderson, R., Tatham, \& Black, W. (1998). (1998). Multivariate data analysis. New Jersey: USA: Englewood Cliffs.

Helbig, N., il-Garcia, J., \& Ferro, E. (2009). Understanding the complexity of electronic government: implication from digital divide literature. Government Information Quarterly, 26(1), 89-97. https://doi.org/10.1016/j.giq.2008.05.004

Hilbert, M. (2011). Digital gender divide or technologically empowered women in developing countries? A typical case of lies, damned lies, and statistics. Women's Studies International Forum, 34(6), 479-489. https://doi.org/10.1016/j.wsif.2011.07.001

Hoofnagle, C., King, J., Li, S., \& Turow, J. (2010). How different are young adults from older adults when it comes to information privacy attitudes and policies?. SSRN Electronic Journal. 
https://doi.org/10.2139/ssrn.1589864

Hu, L., \& Bentler, P. (1999). Cut-off Criteria for Fit Indexes in Covariance Structure Analysis: Conventional Criteria Versus New Alternatives,. Structural Equation Modelling, 6(1), 1-55. https://doi.org/10.1080/10705519909540118

Imhonopi, D., \& Urim, U. (2015). Information and communication technology (ICT) and governance in Nigeria: Challenges and prospect. Journal of Humanities, Social Science and Creative Arts, 1-14.

Kuo, Y.-F., Wub, C.-M., \& Deng, W.-J. (2009). The relationships among service quality, perceived value, customer satisfaction, and post-purchase intention in mobile value-added services. Computers in Human Behaviour, 25(4), 887-896.

https://doi.org/10.1016/j.chb.2009.03.003

Lenhart, A., Purcell, K., Smith, A., \& Zickuhr, K. (2010). Social media \& mobile Internet use among teens and young adults. Millennials. NY: Pew Internet \& American Life Project.

Loges, W., \& Jung, J. (2001). Exploring the digital divide: Internet connectedness and age. Communication Research, 28(4), 536-562. https://doi.org/10.1177/009365001028004007

Ma, Q., Chan, A. H., \& Chen, K. (2016). Personal and others factors affecting acceptance of smart phone technology by elder Chinese adults. Applied Ergonomics, 54, 62-71. https://doi.org/10.1016/j.apergo.2015.11.015

Meuter, M. L., Ostrom, A. L., Bitner, M. J., \& Roundtree, R. (2003). The influence of technology anxiety on consumer use and experiences with self-service technologies. Journal of Business Research, 56(11), 899-906. https://doi.org/10.1016/S0148-2963(01)00276-4

Miloševic, I., Zivkovic, D., Manasijevic, D., \& Nikolic, D. (2015). The effects of the intended behaviour of students in the use of M-learning. Computers in Human Behaviour, 51, 207-215. https://doi.org/10.1016/j.chb.2015.04.041

Min, S. (2010). From the digital divide to the democratic divide: Internet skills, political interest, and the second-level digital divide in political Internet use. Journal of Information Technology \& Politics, 7(1), 22-35. https://doi.org/10.1080/19331680903109402

Norris, P. (2000). The worldwide digital divide: information poverty, the Internet and development. Harvard University.

Norris, P. (2006). The worldwide digital divide: Information poverty, the Internet, and development. Annual Meeting of the Political Studies.

Park, P., \& Kim, G. (2015). Same access, different uses, and the persistent digital divide between urban and rural Internet users. Social Science Research Network.

Pilling, D., \& Boeltzig, H. (2007). Moving toward e-government - effective strategies for increasing access and use of the internet among non-internet users in the U.S. and U.K. 8th Annual International Conference on Digital Government Research: Bridging Disciplines \& Domains Philadelphia ACM International Conference Proceeding Series 228 Digital 
Government Research Centre (pp. 20-23). Philadelphia: ACM International Conference.

Puspitasari, L., \& Ishii, K. (2016). Digital divides and mobile Internet in Indonesia: Impact of smartphones. Telematics and Informatics, 33(2), 472-483.

https://doi.org/10.1016/j.tele.2015.11.001

Rauniar, R., Rawski, G., Yang, J., \& Johnson, B. (2014). Technology acceptance model (TAM) and social media usage: An empirical study on Facebook. Journal of Enterprise Information Management, 27(1), 6-30. https://doi.org/10.1108/JEIM-04-2012-0011

Rossel, P., \& finger, M. (2007). Conceptualizing e-governance. First International Conference on Theory and Practice of Electronic Governance ACM International (pp. 10-13). Macau, China: ACM Publications. https://doi.org/10.1145/1328057.1328141

Servon, L., \& Nelson, M. (2001). Community technology centers: Narrowing the digital divide in low-income, urban communities. Journal of Urban Affairs, 23(3-4), 279-290. https://doi.org/10.1111/0735-2166.00089

Sipior, J. C., Ward, B. T., \& Connolly, R. (2011). The digital divide and t-government in the United States: using the technology acceptance model to understand usage. European Journal of Information Systems, 20(3), 308-328. https://doi.org/10.1057/ejis.2010.64

Tayo, O., Thompson, R., \& Thompson, E. (2015). Impact of the digital divide on computer use and Internet access on the poor in Nigeria. Journal of Education and Learning, 5(1), 1-6. https://doi.org/10.5539/jel.v5n1p1

Vicente, M., \& Lopez, A. (2011). Assessing the regional digital divide across the European Union-27. Telecommunications Policy, 35(3), 220-237.

https://doi.org/10.1016/j.telpol.2010.12.013

Wang, L., Rau, P.-L. P., \& Salvendy, G. (2011). Older Adults Acceptance of information Technology. Educational Gerontology, 37(12), 1081-1099.

https://doi.org/10.1080/03601277.2010.500588

Wasserman, I., \& Richmond-Abbott, M. (2005). Gender and the Internet: Causes of variation in access, level, and scope of use. Social Science Quarterly, 86(1), 252-270.

https://doi.org/10.1111/j.0038-4941.2005.00301.x

White, C. (2012). Digital divide: if you are reading this, you are one of the lucky ones. Infographics.

Zhong, Z. (2011). From access to usage: The divide of self-reported digital skills among adolescents. Computers \& Education, 56(3), 736-746.

https://doi.org/10.1016/j.compedu.2010.10.016

Zinyama, T., \& Nhema, A. (2016). E-government and development in Zimbabwe: An appraisal. Public Policy and Administration Research, 6(2).

Zulfiqar, S., Sarwar, B., Aziz, S., Chandia, K. E., \& Khan, M. K. (2018). An Analysis of Influence of Business Simulation Games on Business School Students' Attitude and Intention 


\section{Macrothink}

Business and Economic Research

ISSN 2162-4860 2019, Vol. 9, No. 1

toward Entrepreneurial Activities. Journal of Educational computing research, 0(0), 1-25. https://doi.org/10.1177/0735633117746746

\section{Copyright Disclaimer}

The author retain copyright for this article, with first publication rights granted to the journal.

This is an open-access article distributed under the terms and conditions of the Creative Commons Attribution license (http://creativecommons.org/licenses/by/3.0/). 